\title{
Variability of Grammatical Features of Persian Translations by Translators' Gender
}

\author{
Mohammad Javad Moafi \\ Hazrate Masoumeh University, Iran
}

\begin{abstract}
The purpose of the study was to investigate whether there is a meaningful relationship between translators' gender and their translations in terms of such grammatical features as mechanics (misspellings and punctuation), syntax (voice, tense and aspect of verbs), and lexis (SL intrusion and sexually-explicit terms) based on the proposed model, called translation performance with grammatical, textual and sociolinguistic branches. For that reason, the same sample English text was imparted to both female and male translators to be rendered into Persian to ascertain if they vary linguistically, and if they do so, what areas are more frequently different. The sociolinguistic factors as well as textual dimensions of the language were not scrutinized in the study. The participants were 30 male and 30 female undergraduate senior students of English at three universities in Qom, Iran. These 60 participants were selected out of 150 students who scored as high as 6 in the IELTS given to them and showed their English proficiency. By analyzing the data elicited descriptively from each translation, primarily, via $t$ test; only 3 out of 15, variables demonstrated a significant difference between translations made by both genders contributing to the research. Thus, although these 3 variables verify the meaningful relationship between translator's gender and their translation performance, these elements are not enough to indicate that the grammar of translations is significantly different.
\end{abstract}

Index Terms - translation, gender, cultural studies and translation performance

\section{INTRODUCTION}

\section{A. Overview}

According to Flotow (2001), "The combination of gender and translation continues to be a productive and stimulating area of research...." There have been plenty of researches and projects exploring and scrutinizing genderrelated issues. As claimed by Simon (1996), women by and large saw themselves as being marginalized and suppressed by the male-dominated societies throughout the history, and, since women were not allowed to write, they envisaged translation as a means through which they could establish themselves in the language and culture of the dominant groups; i.e. the only outlet to express themselves.

Chamberlain (1988) stated that "the issues relating to gender in the practice of translation are myriad, varying according to the type of text being translated, the language involved, cultural practices and countless other factors" ( $p$. 96). It appears that feminist linguistics as an offshoot from feminism and linguistics, particularly critical discourse analysis, on the one hand, and a simultaneously concerted emphasis on culture from cultural studies, on the other, have made a thought-provoking interface for thinkers to explore. Many gender-related issues, or rather, comparative analyses of gender and other factors have remained intact and need to be addressed properly, despite "a burst of activity around questions of gender in translation in the mid-1990s" (Flotow, 2001). For instance, Perteghella (2008) stated that translation studies, both theory and practice, saw a renewed interest in the analysis of gender and ideology in the 1990s. Also, Simon (1996) wrote about an extensive study of feminist issues surrounding translation studies.

Similar to the present work, another one of the researchers who undertook a study trying to bring gender, ideology and translation together was Leonardi (2007). By selecting Italian novels which had been translated into English as her corpus, she made an attempt to discover whether men and women translate differently in order to "establish a comparative framework for the contrastive analysis of the translation strategies of male and female translators" (Leonardi, 2007, p. 19). Additionally, Leonardi (2007) intended to analyze "the role and effects of ideology-driven shifts in translation as a result of gender differences" (p. 289). She hypothesized that women and men translate differently, and then, some translations may be the result of differences in the translators' as well as the authors' sex, various text types chosen for translation and/or different socio-cultural background (Leonardi, 2007, p. 20). Her methodology was critical contrastive text linguistics by analyzing thematic structure, word order, punctuation, mistranslation, omission, addition as well as grammatical, syntactical, lexical, semantic and pragmatic levels. This analysis also incorporates paratextual and paratranslational materials like forewords and prefaces. Perteghella (2008) believed that Leonardi's (2007) intention was to investigate the differences between ideologically modified or mediated translation choices in light of translation strategies and shifts. In spite of her valuable contribution to bring translation, gender, ideology, style and genre together, perhaps, it would have been better to discern how the same source text had been translated by female and male translators instead of selecting a variety of novels being translated into English. 
There has not been a research done as to discover if there is a problem when translators of both genders attempt to construe a text. No one can deny that the outcome will be different however faithful the translators try to be to the SL on account of the variety of decisions made. If a given text possesses a particular facet, let's say sexually-explicit terms, it may be a better and wiser idea to give it to a special gender of translators that showed that particular characteristic. Hence, the present study sought to investigate how the translators' linguistic performances vary by gender.

\section{Significance of the Study}

As remarked by Hamerlain (2005), translators always bring into a text a number of beliefs and values, and as promoted by Talbot (2003), gender is an ideological prescription for any kind of behavior. There appears to be a lack of research as regards the "differences of linguistic features" in the area of translation resulting from the gender of the translators, and that whether these differences are consistent.

\section{Domain of the Study}

Since there was little work conducted as far as such grammatical features as mechanics, syntax, and lexis were concerned, the present study strived to investigate any possible consistencies revealed by the linguistic differences of the Persian translations of an English text as a result of the gender of the translators without letting the translators know of those particular items under question in order to have valid results. The researcher has formulated the hypothesis that female translators translate some of those particular aspects of a text differently from male translators whilst no significant evidence was found to show that translators' gender plays any role in the way they approach the same text on the whole. Owing to the absence of enough empirical research along the same line, the subject needs to be carried out with various languages for a good amount of time after eliminating all other impertinent variables that might vitiate the outcome of the research.

\section{E. Research Questions}

In this present study, there are two main questions that the researcher was trying to investigate. The first one seems microscopic in the sense that there are certain areas in some texts to be translated which need to be scrutinized such as mechanics (misspellings and punctuation), syntax (voice, tense and aspect of verbs), and lexis (SL intrusion and sexually-explicit terms) as part of the grammatical features based on the proposed model, called translation performance with grammatical, textual and sociolinguistic branches. The second, in comparison with the above-mentioned query, appears to be macroscopic. In other words, a bigger picture like the whole text is going to be probed here in this study. Some of these large-scale and small-scale points went unnoticed in previous studies, so to speak. Anyway, the following research questions will be addressed in this research:

Q1: How do translations done by male and female translators differ in the use of such linguistic, or rather grammatical features as mechanics (misspelling and punctuation), syntax (voice, tense and aspect of verbs), and lexis (SL intrusion and sexually-explicit terms)?

Q2: In what areas do translations differ by the gender of their translators? Is grammar different in the translations made by both genders?

\section{F. Research Hypotheses}

The present researcher has made the following hypotheses in order to answer the aforesaid questions based on the model in figure 1.1 below: 


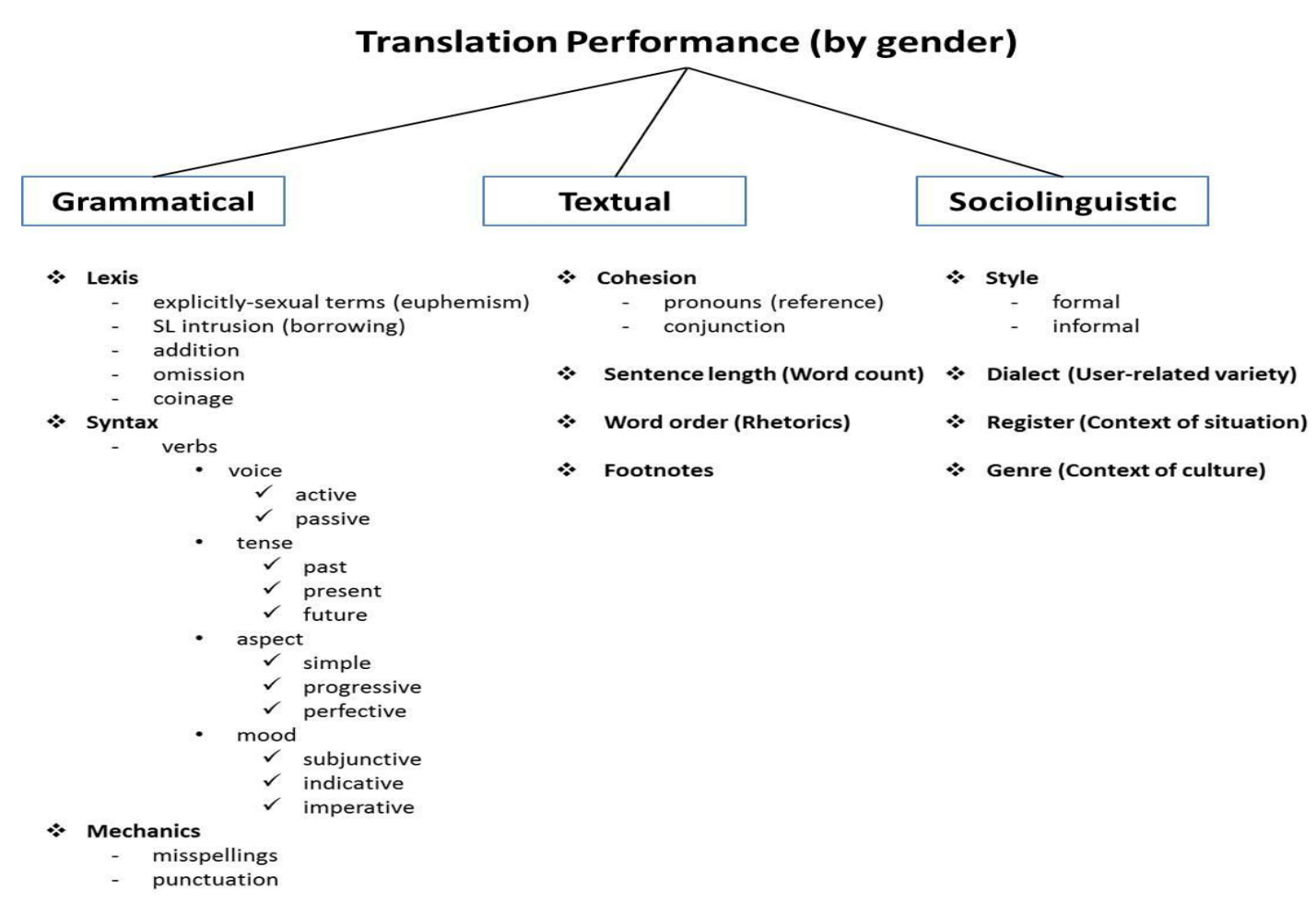

Figure 1.1 The model proposed by the researcher to analyze any given (translated) text with

H1: Female translators translate three of those grammatical aspects of a text differently from male translators: erroneous translation of sexually-explicit terms, use of past-tense and present-tense verbs.

H2: There is no significant evidence demonstrating the fact that translators' gender plays any role in the way they approach the same text in terms of grammar and discourse.

\section{G. Key Terms}

Translation, cultural studies, gender, translation performance

\section{METHODOLOGY}

\section{A. Overview}

The researcher was trying to determine whether there would be a significant difference of grammatical features based on the gender of the translators by descriptively comparing 30 translations rendered by female translators with the same number of translations rendered by male translators. A sample English text was carefully composed of one-paragraph plot outline of Wuthering Heights, Emily Bronte's masterpiece, as well as a passage with a few questions on sex in Wuthering Heights followed by a typical Freudian interpretation and critique. All the three sections of the English passage were imparted a taste of sexually-explicit materials without informing the contributing translators in order to trigger a clear-cut response, or rather, a tell-tale translation. The population was selected from the university English students; i.e. from the eighth semester of the undergraduate level of the State University of Qom, Qom Open University and Azad University, Qom Branch. It is worth mentioning that the respondents were given the IELTS listening, reading and writing sub-tests to reveal their language proficiency to some extent before they commenced translation. This was done so as to rule out any other potentially irrelevant variables tampering the results of the research. Consequently, sixty male and female translators were chosen out of 150 participants in order to have the best of them in the study.

\section{B. Design}

As can be expected, the methodology of academic research papers should follow a rational trend. If there is enough evidence to support the hypothesis after having observed the data, the hypothesis is confirmed; if not, the null hypothesis will apply, or the hypothesis will be disconfirmed. Thus, this research employed an observational method to find out the role translators' gender might play in their translations. The conditions were also controlled to the degree possible in order that the other impertinent variables would not mar the results, and that the conditions would be equal for all participants, both male and female.

The approach was more quantitative than qualitative throughout the research. It was quantitative in the sense that most of the data were in a statistical form, so it was approximately easy for computation and classification. Hence, this study is not only analytical but also strictly descriptive. Accordingly, two major tables were drawn for sorting and summarizing all the data observed in the translations rendered by 60 translators. 


\section{Participants}

The participants of the present research were chosen from among Iranian students who were undergraduate seniors studying English translation at the State University of Qom, Qom Open University and Qom Branch of Azad University. The philosophy behind this type of selection was first they were translation students and they seemed to be perfect individuals who could take part in this study, and second, their level of English proficiency made it much easier to contribute in addition to the advanced level of the sample English text cut out for students as semi-professional translators at a stage near their graduation.

The city Qom was prioritized not only because its students were far more accessible to the researcher at the place of study, but it was safer to have one city in order to limit its atmosphere. Furthermore, the age of students was taken into account so as to bring this factor somewhat under control by keeping it within the range of 23 and 30.

\section{Materials}

The sample English text was composed of a one-paragraph plot outline of Wuthering Heights, one of Emily Bronte's masterpieces, followed by a few general questions on sex in the story along with a typical Freudian interpretation by Linda Gold. The entire material had come from two websites that will be quoted in the reference list. The rationale behind selecting this novel out of many stories was its characteristics that met the researcher's requirements.

There were some items in the sample text that came under grammatical organization of language like lexis, syntax and mechanics. Seventeen sexuality-related terms including sex, sexual passion, losing her cherry, sensual, breast, chastity, illegitimate, incest, sexual force, sexuality, make love, sexual relations, primitive drives, coitus, orgasm, penis and vagina were specified by the researcher as sexually-explicit terms. So, there were four subcategories under the variable sexually-explicit terms, i.e. whether these sexually-explicit words were rendered correctly or incorrectly into Persian, the same English words were used in their translations or omitted in the first place. SL intrusion is another one of those elements that the researcher intended to compare in the two-gender translators' translations. Both sexuallyexplicit terms and SL intrusion which was only a single-subcategory variable are matters of lexis, but any additions and omissions were not calculated due to the scope of this study, and also there was no coinage on the part of the contributing translators so that it could be brought into play.

Verbs which pertain to the syntax of language came under scrutiny too. There were 62 verbs used in the sample text that had been divided by the researcher into the categories of voice, tense and aspect. The present study planned to check if there were any differences between the number of active (58) versus passive (4) voices in both the sample text and the translations attempted by males and females. There was no future tense in the original sample while there were 56 present and 6 past verbs. Any contrast in this regard might be of interest. As for the verb aspect, there were 58 simple and 4 perfect verbs, but no progressive tense. It was left that way, and no progressive verbs were injected so as to see possible shifts on the part of the translators toward this aspect of the verbs. It could be helpful to see which of the two sexes retain the verb aspect of the original text. Thus, on the whole, there were nine subcategories under the variable verbs, i.e. active versus passive voices; past, present and future tenses; simple, progressive and perfect aspects; as well as the total number of verbs itself. However, the mood of the verbs was not gauged owing to the scope of the study.

The last grammatical dimensions were the frequency of misspellings and punctuations. Misspelling had only one subcategory to be checked while punctuation all across their translations was divided into two constituents: proper use of punctuation and poor use of punctuation.

In addition to grammar, textual or discoursal constituents received no attention here, and were left to another study.

\section{E. Procedures}

The procedure of each and every research needs to be planned and organized carefully since it is subtle and vital. The path every research takes determines and influences its results in a particular way. That is why the following procedures were taken throughout the study:

First and foremost, a particular text was found and developed one way or another to meet the intended requirements. In other words, it was coupled with another text of similar nature and adapted to enjoy the features which would lend themselves more easily to investigation. As a case in point, the text should essentially possess enough number of pronouns in order for the researcher to check the references found in their translations. The material required a kind of boost or change to enrich it, let's say, for sexually-explicit terms as an example so as to provide the stimulus for the translators to react.

Another important step was screening the students who were going to be selected to translate the sample text and contribute to the research. Not only for the same reason being mentioned earlier but also for concerns of practicality, validity, reliability and widespread acceptance, an IELTS test was chosen and prepared for as many participants as ready to join. In view of the fact that all the parts of an IELTS package was not basically needed, only the listening, reading and writing subtests were opted and copied according to the number of individuals taking the test. So, speaking subtest, which had not been thought of as helpful due to its nature, was excluded. As Duran et al. (1985) put, "The TOEFL's omission of oral production content is ostensibly justified by research that has shown positive correlations between oral production and the behaviors actually sampled on the TOEFL" [as a standardized proficiency test] although it has been included in recent years (as cited in Brown, 2004, p. 26). Not to mention, for economic reasons as 
well as matters of practicality such as time constraint and large-scale administration, a full examination seemed out of the question. Then, the participants were given the academic-module IELTS to respond under conditions based on its standard guidelines. After two hours and a half, the answers were collected and later corrected.

Only those who scored as high as 6 were granted with the sample text to translate so as to recruit the best and the most suitable participants. The overall band score 6 was chosen owing to the definition of satisfactory level of English which says those who do so "have generally effective command of the language despite some inaccuracies, inapproriacies and misunderstandings, and can use and understand fairly complex language, particularly in familiar situations" (Adams \& Peck, 2000, p. 12). Additionally, it is enlightening to know that most universities all across the globe admit students scoring 6 into English programs and courses.

Next, 60 students 30 of which were female and the rest male were chosen out of 150 individuals being given the IELTS test. These 60 participants were believed to know English at a satisfactory level necessary for the task. On a separate day and time, the chosen students were imparted the sample text the researcher meticulously prepared in advance for the task of translation. Of course, it ought to be noted that prior to their answering the IELTS test as well as translating the sample text for translation, they were informed of the steps of both the IELTS test and the translation task respectively to ensure all of them would understand what to do and to rule out other influencing factors like anxiety caused by confusion. Nevertheless, the participants were not provided with little nuances and features that were going to be investigated in the research in order that their awareness of the grammatical criteria would not affect and bias the results of the study. It was insisted that the conditions remain similar if not the same. For instance, the place of the translation was the class atmosphere for all participants even though there were different classes due to approximately high number of students required to take part in the project so as to achieve an objectively appropriate goal. Another example was all of the participants were allowed to use dictionaries for translation, but not for IELTS.

After collecting the 60 translations done by 30 female and 30 male participants, their prominent characteristics which were the researcher's criteria underwent a close scrutiny. Then, they were tabulated and classified. That is, the features of the variables utilized in the participants' translations were calculated and assigned to the aforesaid tables for the purpose of cozier comparison and analysis. Lastly, all the data, and later the means extracted from each and every translation into the tables, except a set of observed values pertaining to the qualitative variable punctuations that was gauged by Chi-square test, were assessed by the $t$ test to make sure and fathom out which differences are significant. According to Richards, platt and Weber (1985), "Chi-square is a procedure in statistics which is used to determine whether the relationship between two or more variables is independent," and "it measures whether a particular distribution of observed values is sufficiently different from an expected distribution to indicate that it cannot be explained as a chance occurrence." Hatch and Lazaraton (1991) held that the $t$ test is the most felicitous gauge to compare the two means if the comparison is run between two independent samples whereas a matched $t$ test should be applied if the comparison is drawn between two dependent samples, namely, the data comes from the same subjects taking two different tests. This brings the study to the next part that encompasses the date analysis and their results.

\section{DATA AnALYSIS AND RESUltS}

\section{A. Overview}

The present chapter deals with data analysis and results of the study. This study planned to explore the grammatical differences of translations conducted by both sexes of translators. For this reason, first, senior students of English were selected by IELTS to make sure that the most eligible students would be opted to contribute to the research. Next, they were given the same sample text with certain traits to construe so as to reveal differences based on gender of the translators. Yet, the participants were not informed of those characteristics in order that the entire research would not be biased and affected.

The grammatical variables under investigation here consisted of the sexually-explicit terms, SL intrusions, verbs, misspellings and punctuations. Accordingly, the researcher employed a linguistic approach to discover how the performances of male and female translators vary. Having collected their translations, the details related to each variable were extracted and classified. Then, the aforementioned data were analyzed in the form of descriptive statistics as follows:

\section{B. Data Analysis and Results}

TABLE 3.1

THE NUMBER OF CORRECT TRANSLATIONS OF SEXUALLY-EXPLICIT TERMS

\section{Group Statistics}

\begin{tabular}{|l|l|c|c|c|c|}
\hline & sex & $\mathrm{N}$ & Mean & $\begin{array}{c}\text { Std. } \\
\text { Deviation }\end{array}$ & $\begin{array}{c}\text { Std. Error } \\
\text { Mean }\end{array}$ \\
\hline $\begin{array}{l}\text { Correct } \\
\text { translation of } \\
\text { sexually-explicit } \\
\text { terms }\end{array}$ & $\mathrm{M}$ & 30 & 13.17 & 1.683 & .307 \\
\hline
\end{tabular}


TABLE 3.2

RESULTS OF THE T TEST FOR THE NUMBER OF CORRECT TRANSLATIONS OF SEXUALLY-EXPLICIT TERMS

Independent Samples Test

\begin{tabular}{|c|c|c|c|c|c|c|c|c|c|c|}
\hline & & \multicolumn{2}{|c|}{$\begin{array}{l}\text { Levene's Test for } \\
\text { Equality of } \\
\text { Variances }\end{array}$} & \multicolumn{7}{|c|}{ t-test for Equality of Means } \\
\hline & & \multirow[b]{2}{*}{$\mathbf{F}$} & \multirow[b]{2}{*}{ Sig. } & \multirow[b]{2}{*}{$t$} & \multirow[b]{2}{*}{ df } & \multirow{2}{*}{$\begin{array}{c}\text { Sig. } \\
\text { (2-tailed) }\end{array}$} & \multirow{2}{*}{$\begin{array}{c}\text { Mean } \\
\text { Difference }\end{array}$} & \multirow{2}{*}{$\begin{array}{l}\text { Std. Error } \\
\text { Difference }\end{array}$} & \multicolumn{2}{|c|}{$\begin{array}{l}95 \% \text { Confidence } \\
\text { Interval of the } \\
\text { Difference }\end{array}$} \\
\hline & & & & & & & & & Lower & Upper \\
\hline \multirow{2}{*}{$\begin{array}{l}\text { Correct } \\
\text { translation of } \\
\text { sexually-explicit } \\
\text { terms }\end{array}$} & $\begin{array}{l}\text { Equal variances } \\
\text { assumed }\end{array}$ & 6.452 & .014 & 1.877 & 58 & .066 & 1.067 & .568 & -.071 & 2.204 \\
\hline & $\begin{array}{l}\text { Equal variances } \\
\text { not assumed }\end{array}$ & & & 1.877 & 49.482 & .066 & 1.067 & .568 & -.075 & 2.208 \\
\hline
\end{tabular}

As shown by the above computation, there is not a meaningful difference in the number of accurate sexuality-related words translated by both males and females. With the confidence interval of $95 \%$, the $\mathrm{P}$ value was 0.066 which is a more than 0.05 . So, the same calculation demonstrates that there is not a meaningful relationship as far as the variable of correct sexually-explicit terms is concerned.

TABLE 3.3

THE NUMBER OF INCORRECT TRANSLATIONS OF SEXUALLY-EXPLICIT TERMS

Group Statistics

\begin{tabular}{|c|c|c|c|c|c|}
\hline & sex & $\mathbf{N}$ & Mean & $\begin{array}{c}\text { Std. } \\
\text { Dev iation }\end{array}$ & $\begin{array}{c}\text { Std. Error } \\
\text { Mean }\end{array}$ \\
\hline \multirow{2}{*}{$\begin{array}{l}\text { Incorrect } \\
\text { translation of } \\
\text { sexually-explicit } \\
\text { terms }\end{array}$} & M & 30 & 2.4000 & 1.42877 & .26086 \\
\hline & $\mathbf{F}$ & 30 & 3.4667 & 2.11291 & .38576 \\
\hline
\end{tabular}

TABLE 3.4

RESULTS OF THE T TEST FOR THE NUMBER OF INCORRECT TRANSLATIONS OF SEXUALLY-EXPLICIT TERMS

Independent Samples Test

\begin{tabular}{|c|c|c|c|c|c|c|c|c|c|c|}
\hline & & \multicolumn{2}{|c|}{$\begin{array}{l}\text { Levene's Test for } \\
\text { Equality of } \\
\text { Variances }\end{array}$} & \multicolumn{7}{|c|}{ t-test for Equality of Means } \\
\hline & & \multirow[b]{2}{*}{$\mathbf{F}$} & \multirow[b]{2}{*}{ Sig. } & \multirow[b]{2}{*}{$t$} & \multirow[b]{2}{*}{ df } & \multirow{2}{*}{$\underset{\text { (2-tailed) }}{\text { Sig. }}$} & \multirow{2}{*}{$\begin{array}{c}\text { Mean } \\
\text { Difference }\end{array}$} & \multirow{2}{*}{$\begin{array}{l}\text { Std. Error } \\
\text { Difference }\end{array}$} & \multicolumn{2}{|c|}{$\begin{array}{l}95 \% \text { Confidence } \\
\text { Interval of the } \\
\text { Difference }\end{array}$} \\
\hline & & & & & & & & & Lower & Upper \\
\hline \multirow{2}{*}{$\begin{array}{l}\text { Incorrect } \\
\text { translation of } \\
\text { sexually-explicit } \\
\text { terms }\end{array}$} & $\begin{array}{l}\text { Equal variances } \\
\text { assumed }\end{array}$ & 5.948 & .018 & -2.291 & 58 & .026 & -1.06667 & .46568 & -1.99883 & -.13451 \\
\hline & $\begin{array}{l}\text { Equal v ariances } \\
\text { not assumed }\end{array}$ & & & -2.291 & 50.935 & .026 & -1.06667 & .46568 & -2.00159 & -.13175 \\
\hline
\end{tabular}

Given the results obtained from the tables above, there is a meaningful difference in the variable of erroneous sexually-explicit terms calculated from the translations of female and male translators. With the confidence interval of 95 percent, $t$ test was utilized to assess the $\mathrm{P}$ value of the data in this variable. As for the Sig. of 0.026 which was counted by the $t$ test, it can be judged that there exists a meaningful difference between the number of sexually-explicit terms rendered by female translators and the one by male translators because the $\mathrm{P}$ value of this variable was less than 0.05. The mean of the female translators' erroneous sexually-explicit terms was 3.46; and that of male translators, 2.4 .

TABLE 3.5

THE NUMBER OF SL INTRUSIONS OF SEXUALLY-EXPLICIT TERMS

\section{Group Statistics}

\begin{tabular}{|l|l|c|c|c|c|}
\hline & sex & $\mathrm{N}$ & Mean & $\begin{array}{c}\text { Std. } \\
\text { Deviation }\end{array}$ & $\begin{array}{c}\text { Std. Error } \\
\text { Mean }\end{array}$ \\
\hline $\begin{array}{l}\text { SL intrusion of } \\
\text { sexually-explicit } \\
\text { terms }\end{array}$ & $\mathrm{M}$ & 30 & .7333 & 1.20153 & .21937 \\
\hline
\end{tabular}


TABLE 3.6

RESULTS OF THE T TEST FOR THE NUMBER OF SL INTRUSIONS OF SEXUALLY-EXPLICIT TERMS

Independent Samples Test

\begin{tabular}{|c|c|c|c|c|c|c|c|c|c|c|}
\hline & \multicolumn{2}{|c|}{$\begin{array}{l}\text { Levene's Test for } \\
\text { Equality of } \\
\text { Variances }\end{array}$} & \multicolumn{7}{|c|}{ t-test for Equality of Means } \\
\hline & & \multirow[b]{2}{*}{$\mathbf{F}$} & \multirow[b]{2}{*}{ Sig. } & \multirow[b]{2}{*}{$t$} & \multirow[b]{2}{*}{ df } & \multirow{2}{*}{$\begin{array}{c}\text { Sig. } \\
\text { (2-tailed) }\end{array}$} & \multirow{2}{*}{$\begin{array}{c}\text { Mean } \\
\text { Difference }\end{array}$} & \multirow{2}{*}{$\begin{array}{l}\text { Std. Error } \\
\text { Difference }\end{array}$} & \multicolumn{2}{|c|}{$\begin{array}{l}95 \% \text { Confidence } \\
\text { Interval of the } \\
\text { Difference }\end{array}$} \\
\hline & & & & & & & & & Lower & Upper \\
\hline \multirow{2}{*}{$\begin{array}{l}\text { SL intrusion of } \\
\text { sexually-explicit } \\
\text { terms }\end{array}$} & $\begin{array}{l}\text { Equal variances } \\
\text { assumed }\end{array}$ & 1.203 & .277 & 1.364 & 58 & .178 & .36667 & .26874 & -.17128 & .90461 \\
\hline & $\begin{array}{l}\text { Equal variances } \\
\text { not assumed }\end{array}$ & & & 1.364 & 52.222 & .178 & .36667 & .26874 & -.17255 & .90588 \\
\hline
\end{tabular}

Concerning the results gained from the tables above, there is not a meaningful difference in the variable of SL intrusion of sexuality-related terms; namely, the students intruded SL terms in their translations instead of rendering them into Persian. The confidence interval of this test was 95 percent, and the $\mathrm{P}$ value computed from the means of the data was 0.178 which is above the standard Sig. 0.05 .

TABLE 3.7

THE NUMBER OF SEXUALLY-EXPLICIT TERMS OMITTED

Group Statistics

\begin{tabular}{|c|c|c|c|c|c|}
\hline & sex & $\mathrm{N}$ & Mean & $\begin{array}{c}\text { Std. } \\
\text { Deviation }\end{array}$ & $\begin{array}{l}\text { Std. Error } \\
\text { Mean }\end{array}$ \\
\hline \multirow{2}{*}{$\begin{array}{l}\text { Omission of } \\
\text { sexually-explicit } \\
\text { terms }\end{array}$} & M & 30 & .7000 & 1.08755 & .19856 \\
\hline & $F$ & 30 & 1.1000 & 1.15520 & 21091 \\
\hline
\end{tabular}

TABLE 3.8

RESULTS OF T TEST FOR THE NUMBER OF SEXUALLY-EXPLICIT TERMS OMITTED

\begin{tabular}{|c|c|c|c|c|c|c|c|c|c|c|}
\hline \multicolumn{11}{|c|}{ Independent Samples Test } \\
\hline & & \multicolumn{2}{|c|}{$\begin{array}{l}\text { Levene's Test for } \\
\text { Equality of } \\
\text { Variances }\end{array}$} & \multicolumn{7}{|c|}{ t-test for Equality of Means } \\
\hline & & \multirow[b]{2}{*}{$\mathbf{F}$} & \multirow[b]{2}{*}{ Sig. } & \multirow[b]{2}{*}{$\mathrm{t}$} & \multirow[b]{2}{*}{ df } & \multirow{2}{*}{$\begin{array}{c}\text { Sig. } \\
\text { (2-tailed) }\end{array}$} & \multirow{2}{*}{$\begin{array}{c}\text { Mean } \\
\text { Difference }\end{array}$} & \multirow{2}{*}{$\begin{array}{l}\text { Std. Error } \\
\text { Difference }\end{array}$} & \multicolumn{2}{|c|}{$\begin{array}{l}95 \% \text { Confidence } \\
\text { Interval of the } \\
\text { Difference }\end{array}$} \\
\hline & & & & & & & & & Lower & Upper \\
\hline \multirow{2}{*}{$\begin{array}{l}\text { Omission of } \\
\text { sexually-explicit } \\
\text { terms }\end{array}$} & $\begin{array}{l}\text { Equal variances } \\
\text { assumed }\end{array}$ & .181 & .672 & -1.381 & 58 & .173 & -.40000 & .28967 & -.97984 & .17984 \\
\hline & $\begin{array}{l}\text { Equal variances } \\
\text { not assumed }\end{array}$ & & & -1.381 & 57.790 & .173 & -.40000 & .28967 & -.97988 & .17988 \\
\hline
\end{tabular}

As the above-mentioned tables suggest, there is not a meaningful difference in the number of sexually-explicit terms crossed out of the translations of both sexes of translators. There was $95 \%$ confidence interval in the $t$ test conducted for this variable. The $\mathrm{P}$ value of the test was 0.173 that is higher than 0.05 as the cornerstone. The means of the variable were 1.1 and 0.7 for females and males respectively. Thus, this difference is not significant.

TABLE 3.9

THE NUMBER OF SL INTRUSIONS

Group Statistics

\begin{tabular}{|l|l|c|c|c|c|}
\hline & sex & N & Mean & $\begin{array}{c}\text { Std. } \\
\text { Deviation }\end{array}$ & $\begin{array}{c}\text { Std. Error } \\
\text { Mean }\end{array}$ \\
\hline SL intrusions & M & 30 & 5.83 & 13.734 & 2.507 \\
\cline { 2 - 6 } & F & 30 & 2.33 & 4.452 & .813 \\
\hline
\end{tabular}

TABLE 3.10

RESULTS OF THE T TEST FOR THE NUMBER OF SL INTRUSIONS

Independent Samples Test

\begin{tabular}{|c|c|c|c|c|c|c|c|c|c|c|}
\hline & \multicolumn{2}{|c|}{$\begin{array}{l}\text { Levene's Test for } \\
\text { Equality of } \\
\text { Variances }\end{array}$} & \multicolumn{7}{|c|}{ t-test for Equality of Means } \\
\hline & & \multirow[b]{2}{*}{$\mathbf{F}$} & \multirow[b]{2}{*}{ Sig. } & \multirow[b]{2}{*}{$t$} & \multirow[b]{2}{*}{ df } & \multirow{2}{*}{$\begin{array}{c}\text { Sig. } \\
\text { (2-tailed) }\end{array}$} & \multirow{2}{*}{$\begin{array}{c}\text { Mean } \\
\text { Difference }\end{array}$} & \multirow{2}{*}{$\begin{array}{l}\text { Std. Error } \\
\text { Difference }\end{array}$} & \multicolumn{2}{|c|}{$\begin{array}{l}95 \% \text { Confidence } \\
\text { Interval of the } \\
\text { Difference }\end{array}$} \\
\hline & & & & & & & & & Lower & Upper \\
\hline \multirow{2}{*}{ SL intrusions } & $\begin{array}{l}\text { Equal variances } \\
\text { assumed }\end{array}$ & 4.040 & .049 & 1.328 & 58 & .189 & 3.500 & 2.636 & -1.776 & 8.776 \\
\hline & $\begin{array}{l}\text { Equal variances } \\
\text { not assumed }\end{array}$ & & & 1.328 & 35.027 & .193 & 3.500 & 2.636 & -1.851 & 8.851 \\
\hline
\end{tabular}


As exhibited by the above data, there is not a meaningful difference in the number of SL intrusions utilized by both male and female translators. With the $95 \%$ confidence interval, the Sig. was 0.189 which is a more than 0.05 . It ought to be noted that the means of SL intrusions in both males' and females' translations were 5.83 and 2.33 in the order reported. Consequently, the same information verifies that there is not a meaningful relationship as far as the variable of SL intrusions is concerned.

TABLE 3.11

THE NUMBER OF ACTIVE VERBS

\section{Group Statistics}

\begin{tabular}{|c|c|c|c|c|c|}
\hline & sex & $\mathbf{N}$ & Mean & $\begin{array}{c}\text { Std. } \\
\text { Dev iation }\end{array}$ & $\begin{array}{l}\text { Std. Error } \\
\text { Mean }\end{array}$ \\
\hline \multirow{2}{*}{ Active verbs } & M & 30 & 70.27 & 6.690 & 1.221 \\
\hline & $F$ & 30 & 67.83 & 6.347 & 1.159 \\
\hline
\end{tabular}

TABLE 3.12

RESULTS OF THE T TEST FOR THE NUMBER OF ACTIVE VERBS

Independent Samples Test

\begin{tabular}{|c|c|c|c|c|c|c|c|c|c|c|}
\hline & & \multicolumn{2}{|c|}{$\begin{array}{l}\text { Levene's Test for } \\
\text { Equality of } \\
\text { Variances }\end{array}$} & \multicolumn{7}{|c|}{ t-test for Equality of Means } \\
\hline & & \multirow[b]{2}{*}{$\mathbf{F}$} & \multirow[b]{2}{*}{ Sig. } & \multirow[b]{2}{*}{$t$} & \multirow[b]{2}{*}{ df } & \multirow{2}{*}{$\begin{array}{c}\text { Sig. } \\
\text { (2-tailed) }\end{array}$} & \multirow{2}{*}{$\begin{array}{c}\text { Mean } \\
\text { Difference }\end{array}$} & \multirow{2}{*}{$\begin{array}{l}\text { Std. Error } \\
\text { Difference }\end{array}$} & \multicolumn{2}{|c|}{$\begin{array}{l}95 \% \text { Confidence } \\
\text { Interval of the } \\
\text { Difference }\end{array}$} \\
\hline & & & & & & & & & Lower & Upper \\
\hline \multirow{2}{*}{ Active verbs } & $\begin{array}{l}\text { Equal variances } \\
\text { assumed }\end{array}$ & .254 & .616 & 1.445 & 58 & .154 & 2.433 & 1.684 & -.937 & 5.803 \\
\hline & $\begin{array}{l}\text { Equal variances } \\
\text { not assumed }\end{array}$ & & & 1.445 & 57.840 & .154 & 2.433 & 1.684 & -.937 & 5.804 \\
\hline
\end{tabular}

In view of the results attained from the tables above, there is not a meaningful difference in the variable of active verbs counted from the translations of female and male translators. Having applied the $95 \%$ confidence interval, $t$ test was utilized to assess the $\mathrm{P}$ value of the data in this variable. The mean of the female translators' active verbs was 67.83 ; and that of male translators, 70.27. Considering the Sig. of 0.154 , it can be judged that there is not a meaningful difference between the number of active verbs used by female translators and the one by male translators because the $\mathrm{P}$ value of this variable was less than 0.05 .

TABLE 3.13

THE NUMBER OF PASSIVE VERBS

Group Statistics

\begin{tabular}{|l|l|l|l|c|c|}
\hline & sex & N & Mean & $\begin{array}{c}\text { Std. } \\
\text { Deviation }\end{array}$ & $\begin{array}{c}\text { Std. Error } \\
\text { Mean }\end{array}$ \\
\hline $\begin{array}{l}\text { Passive } \\
\text { verbs }\end{array}$ & M & 30 & 5.9333 & 1.74066 & .31780 \\
\cline { 2 - 6 } & $\mathrm{F}$ & 30 & 5.7667 & 2.07918 & .37960 \\
\hline
\end{tabular}

TABLE 3.14

RESULTS OF THE T TEST FOR THE NUMBER OF PASSIVE VERBS

Independent Samples Test

\begin{tabular}{|c|c|c|c|c|c|c|c|c|c|c|}
\hline & & \multicolumn{2}{|c|}{$\begin{array}{l}\text { Levene's Test for } \\
\text { Equality of } \\
\text { Variances }\end{array}$} & \multicolumn{7}{|c|}{ t-test for Equality of Means } \\
\hline & & \multirow[b]{2}{*}{$\mathbf{F}$} & \multirow[b]{2}{*}{ Sig. } & \multirow[b]{2}{*}{$t$} & \multirow[b]{2}{*}{ df } & \multirow{2}{*}{$\begin{array}{c}\text { Sig. } \\
\text { (2-tailed) }\end{array}$} & \multirow{2}{*}{$\begin{array}{c}\text { Mean } \\
\text { Difference }\end{array}$} & \multirow{2}{*}{$\begin{array}{l}\text { Std. Error } \\
\text { Difference }\end{array}$} & \multicolumn{2}{|c|}{$\begin{array}{l}95 \% \text { Confidence } \\
\text { Interval of the } \\
\text { Difference }\end{array}$} \\
\hline & & & & & & & & & Lower & Upper \\
\hline \multirow{2}{*}{$\begin{array}{l}\text { Passive } \\
\text { verbs }\end{array}$} & $\begin{array}{l}\text { Equal variances } \\
\text { assumed }\end{array}$ & .892 & .349 & .337 & 58 & .738 & .16667 & .49507 & -.82433 & 1.15766 \\
\hline & $\begin{array}{l}\text { Equal variances } \\
\text { not assumed }\end{array}$ & & & .337 & 56.260 & .738 & .16667 & .49507 & -.82498 & 1.15831 \\
\hline
\end{tabular}

In light of the tables drawn above, there is not a meaningful difference in the variable of passive verbs used in the translations of both groups of translators. The confidence interval of this test was 95 percent, and the $\mathrm{P}$ value figured out from the means of the data was 0.738 which is above the standard one, i.e. 0.05 . It is worth mentioning that the mean for female individuals was 5.76 while the mean for their male peers was 5.93 . 
TABLE 3.15

THE NUMBER OF PAST VERBS

Group Statistics

\begin{tabular}{|l|l|c|c|c|c|}
\hline & sex & N & Mean & $\begin{array}{c}\text { Std. } \\
\text { Deviation }\end{array}$ & $\begin{array}{c}\text { Std. Error } \\
\text { Mean }\end{array}$ \\
\hline \multirow{2}{*}{ Past-tense verbs } & M & 30 & 20.67 & 9.904 & 1.808 \\
\cline { 2 - 6 } & F & 30 & 27.63 & 14.670 & 2.678 \\
\hline
\end{tabular}

TABLE 3.16

RESULTS OF THET TEST FOR THE NUMBER OF PAST VERBS

Independent Samples Test

\begin{tabular}{|c|c|c|c|c|c|c|c|c|c|c|}
\hline & & \multicolumn{2}{|c|}{$\begin{array}{l}\text { Levene's Test for } \\
\text { Equality of } \\
\text { Variances }\end{array}$} & \multicolumn{7}{|c|}{ t-test for Equality of Means } \\
\hline & & \multirow[b]{2}{*}{$\mathbf{F}$} & \multirow[b]{2}{*}{ Sig. } & \multirow[b]{2}{*}{$t$} & \multirow[b]{2}{*}{$\mathrm{df}$} & \multirow{2}{*}{$\begin{array}{c}\text { Sig. } \\
\text { (2-tailed) }\end{array}$} & \multirow{2}{*}{$\begin{array}{c}\text { Mean } \\
\text { Difference }\end{array}$} & \multirow{2}{*}{$\begin{array}{l}\text { Std. Error } \\
\text { Difference }\end{array}$} & \multicolumn{2}{|c|}{$\begin{array}{l}95 \% \text { Confidence } \\
\text { Interval of the } \\
\text { Difference }\end{array}$} \\
\hline & & & & & & & & & Lower & Upper \\
\hline \multirow{2}{*}{ Past-tense verbs } & $\begin{array}{l}\text { Equal variances } \\
\text { assumed }\end{array}$ & 7.410 & .009 & -2.156 & 58 & .035 & -6.967 & 3.232 & -13.435 & -.498 \\
\hline & $\begin{array}{l}\text { Equal v ariances } \\
\text { not assumed }\end{array}$ & & & -2.156 & 50.889 & .036 & -6.967 & 3.232 & -13.455 & -.479 \\
\hline
\end{tabular}

As put forward by the above-cited tables, there exists a meaningful difference in the number of past verbs used in the translations of both genders of translators. There was 95\% confidence interval in the $t$ test carried out for this variable. The $\mathrm{P}$ value of the test was 0.036 that is less than 0.05 as the criterion of all the $t$ tests. The means of the variable were 27.63 and 20.67 for females and males respectively. As a result, this difference is significant.

TABLE 3.17

THE NUMBER OF PRESENT VERBS

Group Statistics

\begin{tabular}{|c|c|c|c|c|c|}
\hline & $\operatorname{sex}$ & $\mathbf{N}$ & Mean & $\begin{array}{c}\text { Std. } \\
\text { Deviation }\end{array}$ & $\begin{array}{l}\text { Std. Error } \\
\text { Mean }\end{array}$ \\
\hline \multirow{2}{*}{ Present-tense verbs } & M & 30 & 56.8667 & 12.32249 & 2.24977 \\
\hline & $\mathbf{F}$ & 30 & 45.8000 & 16.37997 & 2.99056 \\
\hline
\end{tabular}

TABLE 3.18

RESULTS OF THE T TEST FOR THE NUMBER OF PRESENT VERBS

Independent Samples Test

\begin{tabular}{|c|c|c|c|c|c|c|c|c|c|c|}
\hline & \multicolumn{2}{|c|}{$\begin{array}{l}\text { Levene's Test for } \\
\text { Equality of } \\
\text { Variances }\end{array}$} & \multicolumn{7}{|c|}{ t-test for Equality of Means } \\
\hline & & \multirow[b]{2}{*}{$\mathbf{F}$} & \multirow[b]{2}{*}{ Sig. } & \multirow[b]{2}{*}{$\mathrm{t}$} & \multirow[b]{2}{*}{ df } & \multirow{2}{*}{$\begin{array}{c}\text { Sig. } \\
\text { (2-tailed) }\end{array}$} & \multirow{2}{*}{$\begin{array}{c}\text { Mean } \\
\text { Difference }\end{array}$} & \multirow{2}{*}{$\begin{array}{l}\text { Std. Error } \\
\text { Difference }\end{array}$} & \multicolumn{2}{|c|}{$\begin{array}{l}95 \% \text { Confidence } \\
\text { Interval of the } \\
\text { Difference }\end{array}$} \\
\hline & & & & & & & & & Lower & Upper \\
\hline \multirow{2}{*}{ Present-tense verbs } & $\begin{array}{l}\text { Equal v ariances } \\
\text { assumed }\end{array}$ & 4.804 & .032 & 2.957 & 58 & .004 & 11.06667 & 3.74231 & 3.57561 & 18.5577 \\
\hline & $\begin{array}{l}\text { Equal v ariances } \\
\text { not assumed }\end{array}$ & & & 2.957 & 53.862 & .005 & 11.06667 & 3.74231 & 3.56334 & 18.5700 \\
\hline
\end{tabular}

According to the tables above, there is a meaningful difference in the variable of present verbs used in the translations of both genders. The confidence interval was 95 percent, and the $\mathrm{P}$ value computed via the $t$ test was 0.005 which is a lot less than 0.05 . The means for both male and female participants were 56.86 and 45.8 respectively. Therefore, the difference between the number of present verbs used by male translators and that of the ones employed by their female counterparts is highly significant.

Since there had not been any future-tense verbs in the ST and the fact that neither females nor males made use of future verbs in their translations, the statistics for this variable was zero, and hence no meaningful relationship. The original sample text had been void of the future tense, and it was intentionally left intact to ascertain whether it could be exploited by any participants, or rather, any specific group of translators. So, the text was not injected with the previously-mentioned tense. If positive, it could have been one of those areas that the performance of both genders of translators varies. Be that as it may, neither of the sexes employed this tense in their translations. 
TABLE 3.19

THE NUMBER OF SIMPLE VERBS

Group Statistics

\begin{tabular}{|l|l|c|c|c|c|}
\hline & sex & N & Mean & $\begin{array}{c}\text { Std. } \\
\text { Deviation }\end{array}$ & $\begin{array}{c}\text { Std. Error } \\
\text { Mean }\end{array}$ \\
\hline \multirow{2}{*}{ Simple verbs } & M & 30 & 85.03 & 110.058 & 20.094 \\
\cline { 2 - 6 } & F & 30 & 62.77 & 8.866 & 1.619 \\
\hline
\end{tabular}

TABLE 3.20

RESULTS OF THE T TEST FOR THE NUMBER OF SIMPLE VERBS

Independent Samples Test

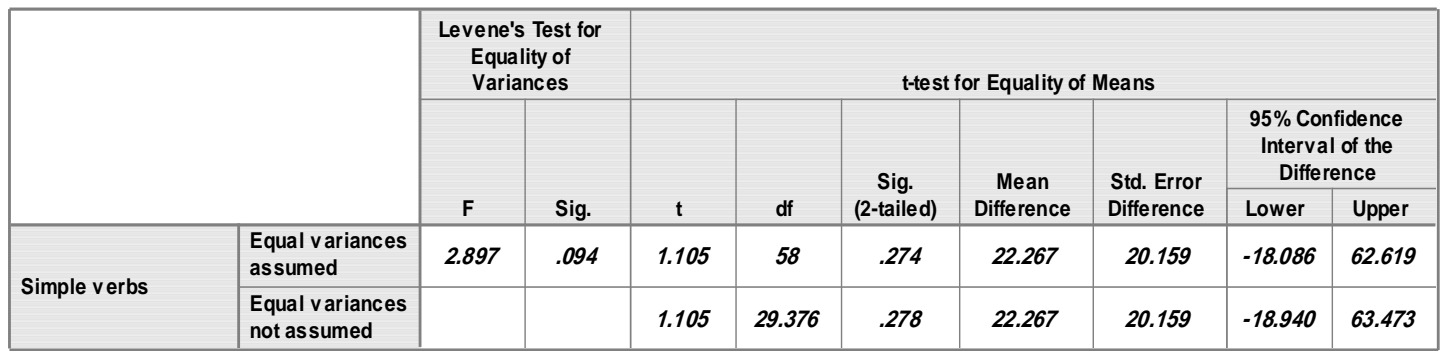

As displayed by the above tables, there is not a meaningful difference in the number of simple verbs utilized by both male and female translators, as far as the variable of aspect is concerned. With the 95\% confidence interval, the Sig. was calculated 0.274 by the $t$ test, which is a more than 0.05 . It is, however, to be noted that the means of simple verbs in both males' and females' translations were 85.03 and 62.77 in the order mentioned. Inevitably, the same information justifies that there is not a meaningful relationship.

TABLE 3.21

THE NUMBER OF PROGRESSIVE VERBS

Group Statistics

\begin{tabular}{|c|c|c|c|c|c|}
\hline & sex & $\mathbf{N}$ & Mean & $\begin{array}{c}\text { Std. } \\
\text { Deviation }\end{array}$ & $\begin{array}{l}\text { Std. Error } \\
\text { Mean }\end{array}$ \\
\hline \multirow{2}{*}{$\begin{array}{l}\text { Progessive } \\
\text { verbs }\end{array}$} & $M$ & 30 & 2.6333 & 2.34128 & .42746 \\
\hline & $F$ & 30 & 3.2000 & 2.35475 & .42992 \\
\hline
\end{tabular}

TABLE 3.22

RESULTS OF THE T TEST FOR THE NUMBER OF PROGRESSIVE VERBS

Independent Samples Test

\begin{tabular}{|c|c|c|c|c|c|c|c|c|c|c|}
\hline & \multicolumn{2}{|c|}{$\begin{array}{l}\text { Levene's Test for } \\
\text { Equality of } \\
\text { Variances }\end{array}$} & \multicolumn{7}{|c|}{ t-test for Equality of Means } \\
\hline & & \multirow[b]{2}{*}{$F$} & \multirow[b]{2}{*}{ Sig. } & \multirow[b]{2}{*}{$t$} & \multirow[b]{2}{*}{ df } & \multirow{2}{*}{$\begin{array}{c}\text { Sig. } \\
\text { (2-tailed) }\end{array}$} & \multirow{2}{*}{$\begin{array}{c}\text { Mean } \\
\text { Difference }\end{array}$} & \multirow{2}{*}{$\begin{array}{l}\text { Std. Error } \\
\text { Difference }\end{array}$} & \multicolumn{2}{|c|}{$\begin{array}{l}95 \% \text { Confidence } \\
\text { Interval of the } \\
\text { Difference }\end{array}$} \\
\hline & & & & & & & & & Lower & Upper \\
\hline \multirow{2}{*}{$\begin{array}{l}\text { Progessive } \\
\text { verbs }\end{array}$} & $\begin{array}{l}\text { Equal variances } \\
\text { assumed }\end{array}$ & .254 & .616 & -.935 & 58 & .354 & -.56667 & .60626 & -1.78022 & .64689 \\
\hline & $\begin{array}{l}\text { Equal variances } \\
\text { not assumed }\end{array}$ & & & -.935 & 57.998 & .354 & -.56667 & .60626 & -1.78022 & .64689 \\
\hline
\end{tabular}

As illustrated by the above data, there is not a meaningful difference in the number of progressive verbs utilized by both male and female translators. With the $95 \%$ confidence interval, the Sig. was 0.354 which is a more than 0.05 . It is interesting to state that the means of progressive verbs in both males' and females' translations were 2.63 and 3.2 in the order written. On that account, the same information verifies that there is not a meaningful difference in relation to the variable of progressive verbs.

TABLE 3.23

THE NUMBER OF PERFECT VERBS

Group Statistics

\begin{tabular}{|l|l|l|l|c|c|}
\hline & sex & N & Mean & $\begin{array}{c}\text { Std. } \\
\text { Deviation }\end{array}$ & $\begin{array}{c}\text { Std. Error } \\
\text { Mean }\end{array}$ \\
\hline \multirow{2}{*}{ Perfect verbs } & M & 30 & 8.4667 & 3.91930 & .71556 \\
\cline { 2 - 7 } & F & 30 & 6.8667 & 3.74841 & .68436 \\
\hline
\end{tabular}


TABLE 3.24

RESULTS OF THE T TEST FOR THE NUMBER OF PERFECT VERBS

Independent Samples Test

\begin{tabular}{|c|c|c|c|c|c|c|c|c|c|c|}
\hline & \multicolumn{2}{|c|}{$\begin{array}{l}\text { Levene's Test for } \\
\text { Equality of } \\
\text { Variances }\end{array}$} & \multicolumn{7}{|c|}{ t-test for Equality of Means } \\
\hline & & \multirow[b]{2}{*}{$\mathbf{F}$} & \multirow[b]{2}{*}{ Sig. } & \multirow[b]{2}{*}{$t$} & \multirow[b]{2}{*}{ df } & \multirow{2}{*}{$\begin{array}{c}\text { Sig. } \\
\text { (2-tailed) }\end{array}$} & \multirow{2}{*}{$\begin{array}{c}\text { Mean } \\
\text { Difference }\end{array}$} & \multirow{2}{*}{$\begin{array}{l}\text { Std. Error } \\
\text { Difference }\end{array}$} & \multicolumn{2}{|c|}{$\begin{array}{l}95 \% \text { Confidence } \\
\text { Interval of the } \\
\text { Difference }\end{array}$} \\
\hline & & & & & & & & & Lower & Upper \\
\hline \multirow{2}{*}{ Perfect verbs } & $\begin{array}{l}\text { Equal variances } \\
\text { assumed }\end{array}$ & .016 & .899 & 1.616 & 58 & .112 & 1.60000 & .99014 & -.38199 & 3.58199 \\
\hline & $\begin{array}{l}\text { Equal variances } \\
\text { not assumed }\end{array}$ & & & 1.616 & 57.885 & .112 & 1.60000 & .99014 & -.38207 & 3.58207 \\
\hline
\end{tabular}

With respect to the results derived from the tables above, there is not a meaningful difference in the variable of perfect verbs used in the translations of female and male translators. With the application of the $95 \%$ confidence interval, $t$ test was utilized to assess the $\mathrm{P}$ value of the data in this variable which was 0.112 . The mean of the female translators' perfect verbs was 6.86; and that of male translators, 8.46.

TABLE 3.25

THE TOTAL NUMBER OF VERBS

Group Statistics

\begin{tabular}{|l|l|c|c|c|c|}
\hline \multicolumn{2}{|c|}{ sex } & N & Mean & $\begin{array}{c}\text { Std. } \\
\text { Deviation }\end{array}$ & $\begin{array}{c}\text { Std. Error } \\
\text { Mean }\end{array}$ \\
\hline \multirow{2}{*}{ Total verbs } & M & 30 & 76.13 & 6.842 & 1.249 \\
\cline { 2 - 6 } & F & 30 & 73.80 & 6.277 & 1.146 \\
\hline
\end{tabular}

TABLE 3.26

RESULTS OF THE T TEST FOR THE TOTAL NUMBER OF VERBS

Independent Samples Test

\begin{tabular}{|c|c|c|c|c|c|c|c|c|c|c|}
\hline & \multicolumn{2}{|c|}{$\begin{array}{l}\text { Levene's Test for } \\
\text { Equality of } \\
\text { Variances }\end{array}$} & \multicolumn{7}{|c|}{ t-test for Equality of Means } \\
\hline & & \multirow[b]{2}{*}{$\mathbf{F}$} & \multirow[b]{2}{*}{ Sig. } & \multirow[b]{2}{*}{$t$} & \multirow[b]{2}{*}{ df } & \multirow{2}{*}{$\underset{\text { Sig. }}{\text { Sigiled) }}$} & \multirow{2}{*}{$\begin{array}{c}\text { Mean } \\
\text { Difference }\end{array}$} & \multirow{2}{*}{$\begin{array}{l}\text { Std. Error } \\
\text { Difference }\end{array}$} & \multicolumn{2}{|c|}{$\begin{array}{l}95 \% \text { Confidence } \\
\text { Interval of the } \\
\text { Difference }\end{array}$} \\
\hline & & & & & & & & & Lower & Upper \\
\hline \multirow{2}{*}{ Total verbs } & $\begin{array}{l}\text { Equal variances } \\
\text { assumed }\end{array}$ & .256 & .615 & 1.376 & 58 & .174 & 2.333 & 1.695 & -1.060 & 5.727 \\
\hline & $\begin{array}{l}\text { Equal variances } \\
\text { not assumed }\end{array}$ & & & 1.376 & 57.576 & .174 & 2.333 & 1.695 & -1.061 & 5.727 \\
\hline
\end{tabular}

In relation to the tables above, there is not a meaningful difference in the total number of verbs used in the translations of both groups. The confidence interval of this test was 95 percent, and the $\mathrm{P}$ value assessed from the means of the data was 0.174 which is above the standard Sig., namely, 0.05 . It is helpful to know that the mean for female individuals was 73.80 while the mean for their male peers was 76.13 .

TABLE 3.27

THE NUMBER OF MISSPELLINGS

Group Statistics

\begin{tabular}{|l|l|l|c|c|c|}
\hline \multicolumn{2}{|c|}{ sex } & N & Mean & $\begin{array}{c}\text { Std. } \\
\text { Deviation }\end{array}$ & $\begin{array}{c}\text { Std. Error } \\
\text { Mean }\end{array}$ \\
\hline \multirow{2}{*}{ Misspellings } & M & 30 & 5.73 & 6.475 & 1.182 \\
\cline { 2 - 6 } & F & 30 & 6.30 & 5.273 & .963 \\
\hline
\end{tabular}

TABLE 3.28

RESULTS OF THE T TEST FOR THE NUMBER OF MISSPELLINGS

Independent Samples Test

\begin{tabular}{|c|c|c|c|c|c|c|c|c|c|c|}
\hline & & \multicolumn{2}{|c|}{$\begin{array}{l}\text { Levene's Test for } \\
\text { Equality of } \\
\text { Variances }\end{array}$} & \multicolumn{7}{|c|}{ t-test for Equality of Means } \\
\hline & & \multirow[b]{2}{*}{$\mathbf{F}$} & \multirow[b]{2}{*}{ Sig. } & \multirow[b]{2}{*}{$t$} & \multirow[b]{2}{*}{ df } & \multirow{2}{*}{$\begin{array}{l}\text { Sig. } \\
\text { (2-tailed) }\end{array}$} & \multirow{2}{*}{$\begin{array}{c}\text { Mean } \\
\text { Difference }\end{array}$} & \multirow{2}{*}{$\begin{array}{l}\text { Std. Error } \\
\text { Difference }\end{array}$} & \multicolumn{2}{|c|}{$\begin{array}{l}95 \% \text { Confidence } \\
\text { Interval of the } \\
\text { Difference }\end{array}$} \\
\hline & & & & & & & & & Lower & Upper \\
\hline \multirow{2}{*}{ Misspellings } & $\begin{array}{l}\text { Equal variances } \\
\text { assumed }\end{array}$ & 1.720 & .195 & -.372 & 58 & .711 & -.567 & 1.525 & -3.618 & 2.485 \\
\hline & $\begin{array}{l}\text { Equal variances } \\
\text { not assumed }\end{array}$ & & & -.372 & 55.714 & .712 & -.567 & 1.525 & -3.621 & 2.488 \\
\hline
\end{tabular}


According to the data above, there is not a meaningful difference in the variable of misspellings occurring in the translations of both sexes. The confidence interval was $95 \%$, and the $\mathrm{P}$ value computed through the $t$ test was 0.711 which is higher than 0.05 . Hence, it can be judged from this portion of research that there is not a meaningful difference as regards this variable.

TABLE 3.29

PUNCTUATION

\begin{tabular}{|l|l|l|c|c|c|}
\hline \multicolumn{2}{|c|}{} & \multicolumn{2}{c|}{ sex } & \multirow{2}{*}{ Total } \\
\cline { 3 - 6 } & \multirow{2}{*}{$\begin{array}{l}\text { Good use } \\
\text { of } \\
\text { punctuation }\end{array}$} & Count & 24 & 20 & 44 \\
\cline { 2 - 6 } $\begin{array}{l}\text { Punctuation } \\
\text { by sex }\end{array}$ & $\%$ of Total & $40.0 \%$ & $33.3 \%$ & $73.3 \%$ \\
\cline { 2 - 6 } & $\begin{array}{l}\text { Poor use of } \\
\text { punctuation }\end{array}$ & Count & 6 & 10 & 16 \\
\cline { 3 - 6 } & \multirow{2}{*}{ Total } & Count & $10.0 \%$ & $16.7 \%$ & $26.7 \%$ \\
\hline & & $\%$ of Total & $50.0 \%$ & $50.0 \%$ & $100.0 \%$ \\
\hline
\end{tabular}

TABLE 3.30

RESULTS OF THE CHI-SQUARE TEST FOR PUNCTUATION

Chi-Square Tests

\begin{tabular}{|c|c|c|c|c|c|}
\hline & Value & df & $\begin{array}{l}\text { Asymp. Sig. } \\
\text { (2-sided) }\end{array}$ & $\begin{array}{l}\text { Exact Sig. } \\
\text { (2-sided) }\end{array}$ & $\begin{array}{l}\text { Exact Sig. } \\
\text { (1-sided) }\end{array}$ \\
\hline Pearson Chi-Square & $1.364^{b}$ & 1 & .243 & & \\
\hline Continuity Correction ${ }^{a}$ & .767 & 1 & .381 & & \\
\hline Likelihood Ratio & 1.375 & 1 & .241 & & \\
\hline Fisher's Exact Test & & & & .382 & .191 \\
\hline $\begin{array}{l}\text { Linear-by-Linear } \\
\text { Association }\end{array}$ & 1.341 & 1 & .247 & & \\
\hline $\mathrm{N}$ of Valid Cases & 60 & & & & \\
\hline
\end{tabular}

As opposed to all the preceding calculations, Chi-square test was employed to assess the Sig. of the tabulated data, for these qualitative data were dealt with here in this part of the study. Correspondingly, the researcher was not to compute the means. But rather, it was about percentages. The whole population was divided into two groups, in addition to their sex, and that was, those translators who made good use of punctuations and those who made poor use of them in their translations. As illustrated by the above-cited tables, there is not a meaningful difference in the way both genders of translators utilize punctuations. There was $95 \%$ confidence interval in the Chi-square executed for this variable. The $\mathrm{P}$ value of the test was 0.243 that is more than 0.05 as the standard criterion. Hence, this information does not indicate any significant difference.

\section{DISCUSSION AND CONCLUSION}

\section{A. Discussion}

As noted earlier, the purpose of this study was to ascertain whether there is any meaningful relationship between the translators' gender and the way they translate the same text. A linguistic approach was applied to the study. In other words, translation performance was branched off into grammar, textuality (discourse) and sociolinguistics. Every one of them was also separated into their own constituents as follows: discourse comprised cohesion (pronouns and conjunctions), sentence length (word count), footnotes and word order (rhetorics) while grammar entailed lexis (sexually-explicit terms and SL intrusions), syntax (verbs) and mechanics (misspellings and punctuations). In contrast, sociolinguistics incorporated style, dialect, register and genre. Most of these major variables, in turn, consisted of some minor, or rather, sub-variables. Of course due to a number of reasons like the limitations given the proportions of this study, only the grammatical dimension of the translation performance was to be investigated here to see if it would reveal any meaningful link between the translators' gender and their translations.

Unlike other researches conducted in the same or similar literature, this study posed new questions on the relationship between gender and translation. Previous literature has been wrestling with the surroundings of the notion of gender and/or sex such as feminism and struggling to look at the issue from a special angle whereas the present study attempted to delve into the heart of the matter. That is to say, a translated text has certain characteristics that other translations created, or even "recreated," by a different translator do not, and the first observable ingredient is the language used in them. However, there were some studies which paved the way for and lent a hand to future work 
ranging from the very early claims of Jespersen's (1922) and Lakoff's (1975), as biased and stereotypical some of them looked, to the latest ones held by Flotow (2002) and Leonardi (2007). Each took the foot of the studies one step forward, so to speak.

For instance, taboos or four-letter words had been a subject that was worked on by the experts in the field. It was believed that women, particularly in collegiate atmosphere, are less prone to use taboos. Earlier to her 1975's research which asserted that women use more (super)polite forms and hypercorrect grammar, Lakoff (1973) concluded that women's insecurity and uncertainty, owing to sexism, resulted in more proper use of the rules of Standard American English grammar that was found in the speech of men (as cited in Fromkin, Rodman \& Hyams, 2003, p. 486). Johnson (1993) spoke of a double standard against women, and disagreed with the conclusion that if women used them, they would be called unladylike. Salami and Awolowo (2006) proved the role gender played in the use of 4-letter words. Notwithstanding, religion was found to have no effect. Owing to the sensitivity of the issue in Iran, the four-letter words were soft-pedaled or trivialized to sexuality-related terms. The researcher was trying to see how many of them the translators would render, or if they do so, whether they translate them correctly or cross out. According to tables $3.1,3.2$ $3.3,3.4,3.5,3.6,3.7$ and 3.8 , about $71.18 \%$ of females and $77.47 \%$ of males translated these terms correctly while $20.35 \%$ of females and $14.12 \%$ of males translated them incorrectly. Only the latter result proved to be significant. So, a higher percentage of males tend to render the sexually-explicit terms correctly. Besides, $2 \%$ of females and $4.29 \%$ of males brought those English words into their translations instead of translating them into Persian. It is interesting to know that $6.47 \%$ of female translators and $4.21 \%$ of males omitted the aforesaid words. However, the last two results did not show a meaningful relationship. Anyhow, that the frequency of taboos is lower in women's language is not apparently verified or implied by the present study since the rationale behind insertion of such terms in the sample English text in the first place had been to see if female translators would avoid them for any reasons like leaving these delicate words out of their translations. It was contrastively observed that women translated such touchy words just as men did, at least in this corner of the globe and at this juncture of time.

As exhibited by tables 3.9 and 3.10 in the previous part, the number of SL intrusions (as another element of lexis) was calculated in both groups' translations although it could not show any meaningful distinction between their texts. This subject is still fresh and requires to be tested further with more cases and languages.

As demonstrated by tables 3.11, 3.12, 3.13 and 3.14 that were related to the voice of the verbs used in the translations of both sexes, it seemed that there was no meaningful relationship between gender and the voice of the verbs, as far as syntax is concerned. In other words, gender played no role in the number of active and/or passive voices available in the translated texts of the same ST rendered by both sexes. The finding of this section of the study agreed with Sterkel's (1988) analysis of 108 students' business communication writing styles at Colorado University in that no relationship could be detected and established between gender of the translator and the number of passive voices used in their texts.

Given the tense of the verbs, both the past and the present tenses were found to be meaningfully significant in the sense that although female translators employed more past-tense verbs, they tended to use fewer present-tense verbs in their translations. These statistical results belong to the tables 3.15, 3.16, 3.17 and 3.18 in the section on data analysis and results. However, no tables were drawn for the future tense because the sample text did not possess any future-tense verbs and it remained untouched in order to witness possible shifts toward this particular tense in the translations by either group, but neither males nor females showed any tendency to use this tense in place of other tenses.

Tables 3.19 and 3.20 suggested that there was no significant difference between number of simple verbs used in males' translations and that of females' ones, as far as aspect of the verbs under syntax is concerned. As cited before and displayed by tables 3.21 and 3.22, the original sample text given to all the participants had been void of progressive verbs, and it was kept that way. That is, it was not enriched with any progressive verbs to see if the translators of any sex would like to take advantage of this aspect in their Persian translations. Although some individuals of either gender employed this aspect a few times, the $t$ test indicated no significance as for the difference. In view of the perfect verbs as another important aspect in both English and Persian which were reflected in tables 3.23 and 3.24, a meaningful relation could not be found due to the resemblance of the number of perfect verbs used in both genders' translations. The final item pertaining to the domain of verbs that was investigated in the study was the total number of verbs utilized in the translations attempted by both groups. The P value of the tables 3.25 and 3.26 that was higher than 0.05 did not show any significance on the aggregate.

Another fresh subject that was touched on here was misspellings (as an element of mechanics) although it rendered to be insignificant. Based on the tables 3.27 and 3.28, the study could not show that there was a meaningful difference between the number of misspellings present in male translations and in the translations of their counterparts. Likewise, punctuation, which was also a new issue under investigation, did not show any difference between male and female translations. The mere difference this variable had with all the other variables going under scrutiny here was that since it had been a qualitative issue, it needed to be computed by a different test. That is why its calculation was carried out by Chi-square test even though the difference was not significant, as revealed by tables 3.29 and 3.30. However, it is enlightening to know that the percentage of male translators $(80 \%)$ who had good use of punctuations was four times as much as males (20\%) that had poor use whereas the percentage of female translators $(66.66 \%)$ who had good use of punctuations was approximately twice as much as that of those females (33.34\%) that had poor use. 
Last but not the least, 67\% (20 cases) of women did not translate the most important part of the title of the sample text, i.e. Wuthering Heights whilst about the same percentage (67\% or 20 cases) of men translated one or both part(s) of the aforesaid proper noun.

\section{B. Conclusion}

The purpose of the present study was to ascertain whether the translations attempted by male and female participants would vary linguistically. The result of the study showed that both hypotheses were verified. In other words, six linguistic features were observed to be significantly different. However, this was not enough to conclude that grammar and discourse in the translations of both genders are meaningfully different. For that reason, such linguistic features as lexis (sexually-explicit terms and SL intrusion), syntax (voice, tense and aspect of verbs) and mechanics (misspellings and punctuation) were scrutinized through a thorough scan of the translations of those individuals contributing to the study. Each of the above-mentioned variables were also divided into their own subcategories, and later tabulated for easier analysis. The researcher employed a rather descriptive procedure due to the quantitative nature of the research and the classification of the statistics. Since some of the areas under investigation were quite fresh with almost little background, this study appeared to pioneer some areas of grammatical factors organizing each and every translation performance. However, the textual facets as well as sociolinguistic dimensions were not touched on here.

Far few linguistic features, along the same line, had been descriptively assessed. Many ideas regarding the distinction in language use between the males and females had been purported, yet only a few of them were put to test, and at times if some scholars did so, they went too far, jumped the conclusion, and/or generalized their findings.

Hence, upon close examinations of the statistics derived from the preceding tables, it is observed that six of the variables, assessed by the $t$ test, were meaningfully different between female and male translators. They are as follows:

1. Male translators rendered sexually-explicit terms more correctly than females.

2. Female translators used more past-tense verbs than their male peers.

3. Males utilized more present-tense verbs vis-à-vis females.

\section{Implications of the Study}

The goal this study sought to achieve was to ascertain the variability of linguistic features in the translations of English texts into Persian. It was hoped that the findings of the study would set the theoretical stage for analysis of the interaction between gender and translation since some of these grammatical characteristics had not undergone descriptive scrutiny. It has long been claimed that the language of men and women are dissimilar, still the constituent ingredients of language, here, translation seem to have been neglected because tremendous amount of heed, constantly and increasingly, is being paid to sociolinguistic and functional aspects. It is true that these crucial categories affect the outcome, or for want of a better term, the language used in translation, but it is to be noted that the twists and turns of the "modern" theories in the field should not make the researchers overlook, or rather, downplay the role of discourse and grammar as the most observable part and parcel of language. As a case in point, apart from better understanding the linguistic differences between the translations attempted by male and female translators in Iran, the present research helps discern a good translator from among a population with a specific sex to be more efficient when dealing with a particular text, say, with a higher rate of sexually-explicit terms.

\section{Limitations of the Study}

One of the problems that most studies have in common is the number of participants contributing to the study. Though adequate it may sound, 60 individuals (30 females and 30 males) might be a small population to deduce and induce theories for sure. Of course, this population was the result of screening 150 undergraduate senior students of English. When they are screened by IELTS or any other proficiency tests to assess their knowledge and command of English, merely a few of them are capable of passing the examination and meeting the requirements. In order to accumulate 30 participants on each side of the continuum of gender, the researcher had to resort to various classes that might have had a spectrum of individuals with a variety of conditions, which made the road bumpy at first. Some participants might have a "shaded identity," meaning that they do not belong to a specific gender definitely because the borderline between the two genders is not so clear-cut. Sporadically, they might blur the findings and impair the results. Not to mention, the findings could have been boosted by more professional participants than simply the ones elicited from translations rendered by B.A. senior students of English.

In addition to the vast amount of time such field studies consume, motivation posed a grave challenge. It was excruciatingly difficult to persuade everyone to partake in the study, and if they do so, they attach enough importance and take it seriously. Another limitation that the present study was grappling with had been such variables as race and ethnicity. People from a particular place may have a particular mentality. Of course, the present research took place in Qom, Iran so as to strive to retain these variables constant although there are always immigrants everywhere. Age was kept within the range of 23 and 30 to somewhat bring it under control. Perhaps it could have been better if this range had been more limited. Similarly, the applicants' exposure to English like movies, magazines, novels, etc. could not have been brought under control. Coates (1986) nicely maintained that "social differentiation in language does not exist in a vacuum; it interacts in a complex way with other kinds of social differentiation" (p. 204). However, it is too 
grueling to take into consideration such variables as religion, mental attitude, cultural background, social class, economic status and so forth. Last but not the least, textual and sociolinguistic features were not captured in this study.

\section{E. Suggestions for Further Research}

The domain of activities within the interaction between gender studies and translation studies is so immense and novel that all the work done hitherto looks like a newborn baby in comparison with the developments in other studies. As Flotow (2001) pointed out, "A number of recent, everyday examples of gender in translation are a sign that the topic is not only hard to kill but can provide material for impassioned discussion" (p. 2).

By virtue of the very fact that there were some limitations in the present study, the following suggestions were made to nurture the research, particularly through more comparative means:

1. Sociolinguistic and textual factors need to be injected into the study as separate and independent variables to discover what results they will bring about, and how they will vary.

2. Much more participants may be incorporated into the study to yield a better and more reliable result.

3. Such variables as religion, mental attitude, cultural background, social class, economic status, etc., if thought of and inserted into the study, may be decisive in the outcome. It can be highly efficacious to bring those elements into play.

4. The present research concentrated on written translation. It is recommendable to see the results by examining the oral translation, or better, interpretation.

5. Other textual genres could be selected to see what happens to the results.

6. It will be helpful and constructive to encompass other grammatical features like coordinate structures, subordinate clauses, expressions, idioms and sentence type, i.e. simple, compound, complex or a combination.

7. More professional individuals may be hired or urged to join the project.

8. Finally, there should be something done to remove the obstacle of motivation on the part of participants since they pay little attention to the study if they ever take part. Economic assistance may be of help occasionally.

\section{REFERENCES}

[1] Adams, G. \& Peck, T. (2000). 101 helpful hints for IELTS, p. 12. Sydney: Adams \& Austen Press.

[2] Brown, D. H. (2004). Language assessment. New York: Pearson-Longman.

[3] Chamberlain, L. (1998). Gender Metaphorics in Translation. In Baker, M. (2001). The Routledge encyclopedia of translation studies, pp. 93-96. London and New York: Routledge.

[4] Coates, J, (1986). Women, men and language. London and New York: Longman.

[5] Flotow, L. v. (2001). Gender in Translation: The Issues Go on, Retrieved January 5, 2010, from http://www.orees.concordia.ca/numero2/essai/VonFlotow.html.

[6] Flotow, L. v. (2002). Gender and Translation: From Identities to Pluralities. In Kuhiwczak, P., \& Littau, K. (2007). A companion to translation studies. Clevedon: Multilingual Matters Ltd.

[7] Fromkin, V., Rodman, R., \& Hyams, N. (2003). An introduction to language ( $7^{\text {th }}$ ed.). Massachusetts: Thomson-Heinle.

[8] Hamerlain, S. (2005). Translation as a Transmitter of Feminist Ideology, Annales du patrimoine: 2005. Retrieved February 20 , 2010, from http://annales.univ-mosta.dz/fr3/hamerlain.pdf

[9] Hatch, E., \& Lazaraton, A. (1991). The research manual: Design and statistics for applied linguistics. Boston, MA: Newbury House.

[10] House, J. (1977). A model for translation quality assessment. Tübingen: Narr.

[11] Jespersen, O. (1922). Language: Its nature, development and origin. Boston: Unwin Hyman.

[12] Johnson, J. L. (1993). A Descriptive Study of Gender Differences in Proscribed Language Behavior, Beliefs, and Attitudes. Paper Presented at the Annual Meeting of the National Council of Teachers of English, Pittsburgh, PA. Retrieved March 1, 2009, from http://eric.ed.gov/ERICDocs/data/ericdocs2sq1/content_storage_01/0000019b/80/15/36/00.pdf

[13] Lakoff, R. (1973). Language and women's place. Language in Society, 2: 45-80. In Fromkin, V., Rodman, R., \& Hyams, N. (2003). An introduction to language $\left(7^{\text {th }}\right.$ ed.). Massachusetts: Thomson-Heinle.

[14] Lakoff, R. (1975). Language and woman's place. New York: Harper \& Row.

[15] Leonardi, V. (2007). Gender and ideology in translation: Do women and men translate differently? A contrastive investigation of translations from Italian into English. New York: Peter Lang AG.

[16] One-paragraph plot outline of Wuthering Heights. (n.d.) Retrieved November 3, 2009, from http://summarycentral.tripod.com/wutheringheights.htm

[17] Perteghella, M. (2008). A Review of Leonardi, V. (2007). The Journal of Specialized Translation: July 2008, Issue 10, pp. 157159.

[18] Richards, J., Platt, J., \& Weber, H. (1985). Longman dictionary of applied linguistics. New York: Longman.

[19] Salami, L. O., \& Awolowo, O. (2006). Use and Attitude Towards English Taboo Words Among Young adults in a Nigerian University. International Journal of Language, Society and Culture: 2006, Vol. 17. Retrieved February 5, 2010, from http://www.educ.utas.edu.au/users/tle/journal/articles/2006/17-4.htm

[20] Sex in Wuthering Heights and a Freudian interpretation. (n.d.) Retrieved November 3, 2009, from http://academic.brooklyn.cuny.edu/english/melani/novel

[21] Simon, S. (1996). Gender in translation: Cultural identity and the politics of transmission. London and New York: Routledge.

[22] Sterkel, K. S. (1988). The Relationship between Gender and Writing Style In Business Communications. Journal of Business Communication: April 1988, pp. 17-39. 
[23] Talbot, M. (2003). Gender Stereotypes: Reproduction and Challenge. In Holmes, J., \& Meyerhoff, M. (2003). The handbook of language and gender, pp. 468-86. Oxford: Blackwell.

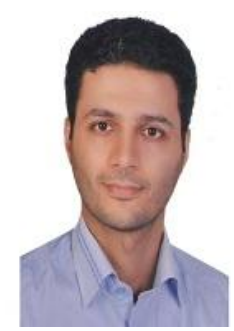

gender studies.

Mr. Moafi has been translating for different centers. He was the Simultaneous Interpreter at the International Conference on Family Law, Tehran, Iran in 2009. He was the Translator of the 1st and 2nd Volumes of the Book "I Talk With God About Everything" (Memorable Days \& Lovely People) in 2012 and "Bam Is Alive" in 2006 at the request of Teachers Training Center of Children and Teenagers affiliated with Islamic Propagation Organization. He was the Translator of "Dordaneh" which was a biography of Grand Ayahatollah Bahjat at the request of his bureau in 2010. He has a Persian article entitled "Semantic Analysis of Sura Ikhlas" published in the Journal "About Translation" affiliated with University of Science and Research, Tehran, Iran in 2010.He has translated the documentary "Mahe Guyan" which was a story on Hojjatolislam Ebrahimi's martyrdom at the request of Channel One of IRIB, Iran in 2008. 